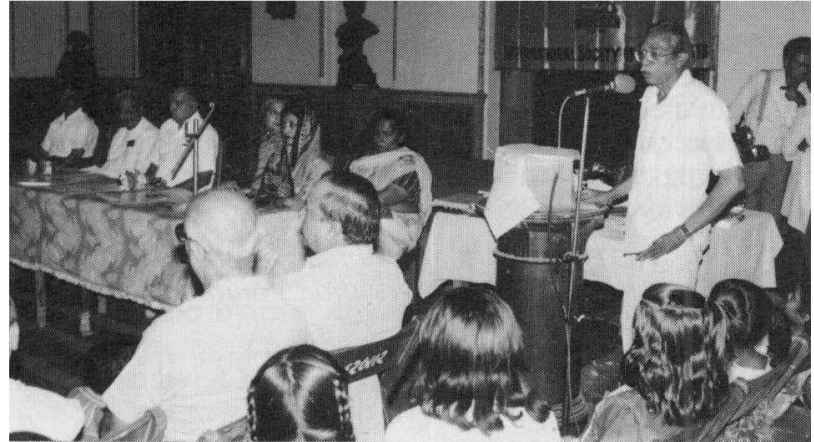

FIG. 2. General Secretary Dr G.M. Oza addressing an 'environmental archivers' meeting of INSONA, with the base of the Society's emblem visible behind him. Photo: Preeti Photographers.

- Members of INSONA gave broadcast talks on the environmental and conservational movements.

- Programmes on Doordarshan Kendra Srinagar and Ahmedabad were given on 'The Role of CITES' (Convention on International Trade in Endangered Species of Fauna and Flora) and 'Illegal Trade in Global Wildlife'.

- Talks on Environment (with AV aids) in various schools for the benefit of both pupils and teachers. On these and more public occasions the audience was often large and enthusiastic (Fig. 1).

- The Press was briefed at regular intervals on environmental issues.

- Skating for Environmental Awareness by hundreds of students.

- INSONA was a partner in the campaign to save the African Elephant (Loxodonta africana). The impact was felt in the CITES Conference through more than one thousand signatures supporting the pledge not to use or promote tusk products.

- Survey of the Bharatpur Kaleodeo National Park to determine the environmental status of the cranes and their habitat.

- Designing of special T-Shirts - on Save Our Biosphere and Environmental Awareness highlighting the Indian Tiger (Felis tigris) and the Blackbuck (Antilope cervicapra).

- Talks delivered by Professor T.A. Davis on 'Man and Nature' and 'the Palms of the World'. These are in addition to 'archivers' and other meetings of INSONA (Fig. 2).

- Competition for schoolchildren to design posters on the well-being of the Earth.

It is hoped that the above gives a fair indication of the range of what can be done by an international concern in its home country despite very limited resources as it feels its way towards wider influence.*

\section{Gunavant M. Oza, General Secretary \\ International Society of Naturalists (INSONA) Indumati Mahal \\ Jawaharlal Nehru Marg \\ Baroda 390 001, India.}

\begin{abstract}
*As, originally, the Indian Society of Naturalists, INSONA was established in the year 1975 by the former Maharaja of Baroda, the late Fatehsinghrao P. Gaekwad, as its Founding President, and with Dr Gunavant M. Oza as its Founding General Secretary. For the past 15 years, the latter has spearheaded various activities, campaigns, and crusades, on behalf of INSONA and such affiliates as our Foundation for Environmental Conservation, aimed at the common well-being of Mankind and Nature. A notable example of such collaboration is the World Campaign for The Biosphere, and an outcome of Dr Oza's personal dedication is the quarterly journal Environmental Awareness, which now has an impressive supporting panel of internationally-known Consulting Editors.

Mrs Premlata Oza, Joint Secretary of INSONA, has extended several aspects of the environmental and conservational movements to schoolchildren and women in India, in a manner that should set a worthy example for other countries and regions. - Ed.
\end{abstract}

\title{
Maurice Strong to be Secretary-General of the UN Conference on Environment and Development
}

The Secretary-General of the United Nations has announced the appointment of Maurice F. Strong as Secretary-General of the United Nations Conference on Environment and Development, to be convened in 1992 in accordance with General Assembly resolution 44/228. Mr Strong, who was our first Baer-Huxley Memorial Lecturer in Iceland in 1977, informed us very recently that this major event, '20 years after Stockholm', would be in Brazil, although it had not yet been decided precisely where in that vast country.

Mr Strong is currently Chairman of Stroevest Holdings in Canada, Chairman of the Council of the World Economic Forum, Geneva, and President of the World Federation of United Nations Associations. From 1985 to 1986, he was Executive Coordinator of the United Nations Office for Emergency Operations in Africa. More pertinently, he was Secretary-General of the 1972 United
Nations Conference on the Human Environment (in Stockholm, Sweden) and subsequently became the first Executive Director of the United Nations Environment Programme.

Maurice Strong's work in development has included heading-up Canada's International Development Assistance Agency, and service as Alternate Governor of the World Bank, the Asian Development Bank, and the Caribbean Development Bank. He has also been President and Chairman of the Board of Petrocanada as well as Chairman or Director of various Canadian and international corporations. Again more pertinently he was a member of the World Commission on Environment and Development and Chairman of the Bureau of IUCN.

Born in 1929 in Manitoba, he is married to Hanne Marstrand, from Denmark.-Ed.

\section{Euro Citizen Action Service}

Euro Citizen Action Service (ECAS) is being set up as a non-profit-making service to inform, advise, and strengthen, thie position of voluntary-sector NGOs in relation to European Community (EC) institutions. It seeks to involve the 'Citizens of Europe' in European affairs, through their membership of organizations in major fields such as health, the environment, human rights, and development.

Whilst there are about 3,000 'watchers' of the EC, few work for public-interest concerns. This imbalance is 
becoming more and more marked as the commercial sector reassesses its strategies in the prospect and light of 1992. The voluntary sector should do likewise if it aspires to avoid being increasingly left out of the decision-making process. ECAS will provide a focal point for NGOs and INGOs (international nongovernmental organizations) in their dealings with EC Institutions, and will help them to overcome the national handicaps that deter them from having an effective 'presence' in Brussels.

The future of the voluntary sector lies with those organizations which have strong European links, and, as 1992 approaches, involvement with EC institutions and issues can no longer be regarded as an optional extra. The voluntary sector is increasingly affected by EC legislation, and if NGOs wish to be consulted on matters which concern them, then they need an effective representation in Brussels.

ECAS does not set out to replace existing NGOs, but rather to offer them a service. It will be a 'consultancy' for the voluntary sector, responding flexibly to the needs of its subscribers and encouraging, wherever possible, direct contacts between NGOs and EC. It will have a small, mainly Brussels-based, board of directors and an advisory council which will be as representative as possible of EC countries and of the interests of its subscribers. Subscribers will pay a basic subscription plus the cost of any additional services used. There will also be founder subscribers who will have considerable input into the advisory council in return for helping ECAS to become established.

ECAS hopes to serve European, international, national, and regional, non-governmental organizations that are independent at once of governments, political parties, and commercial interests. It will provide a range of services, including a basic information and documentation centre, regular briefings about EC activities, reports on issues of common concern to a number of NGOs, office facilities, and briefings for visiting subscriber organizations.

Other services will be offered in accordance with demand: monitoring the work of EC institutions, providing lobbying advice to individual organizations, arranging translation and interpretation services for Brussels meetings, assisting with fund-raising at $\mathrm{EC}$, advising on cooperation with NGOs in other EC countries, providing a 'watching brief' in Brussels, providing legal advice, encouraging the setting up of European public-interest groups, and facilitating European campaigns.

ECAS is currently contacting thousands of NGOs in $\mathrm{EC}$ and other European countries, to assess their particular requirements. If you think your organization might be interested in such a service, then more information may be obtained from:

ANTHONY VENABLES
ECAS
Rue de Toulouse 22
l040 Bruxelles
Belgium.
ECAS $1040 \mathrm{Br}$
Belgium

\section{WWF* Launches Feature Service}

In an attempt to meet the growing demand for toplevel environmental reporting, WWF has launched a global feature service. Produced by the $W W F$ News editorial team, the WWF Feature Service circulars are being sent to major newspapers, magazines, news broadcasters, and film-makers, around the world. WWF's Feature Service provides editors and broadcasters with the latest information available on the critical environmental issues of the day - including tropical forests, wetlands, biological diversity, climate change, pollution, waste management, and energy conservation.

In a pilot series, Donald Allan reports on the death of Barbara D'Achille, a prize-winning environmental journalist, who was killed by 'Shining Path' guerillas while she was on an assignment in the Peruvian Andes. Peter Jackson, Reuters' correspondent in India for nearly 20 years, exposes the violent clashes between rival factions in northeastern India's Assam State that have turned an important Tiger Reserve and World Heritage Site into a battleground. Also in this set of Features, coral-reef

* WWF continues to be known as World Wildlife Fund in Australia, Canada, and the United States of America; in other countries it is now the World Wide Fund For Nature. expert Susan Wells reveals that a recent survey shows how 93 of the 103 countries with significant coral communities are suffering from reef damage. Known as the 'tropical forests of the ocean' for their rich biological diversity, coral reefs are disappearing at an alarming rate.

WWF encourages editors and broadcasters to use the Features in their publications and in news reports. Journalists and announcers may also adapt WWF Features to meet their local news needs, and are invited to request additional information, schedule interviews with WWF representatives, and use the graphics that are provided with each set of Features. Journalists who wish to report on WWF activities are also welcome to submit proposals for the Feature Service. Editors and journalists are requested to send press clippings of published features or to notify the Feature Service of broadcast use. Further information may be obtained from the undersigned (Telephone (022) 6492 22):

ELISABETH KEMPF, Editor WWF Features

WWF International Avenue du Mont-Blanc 1196 Gland, Switzerland.

\section{EuroSolar Association}

Introducing EuroSolar, the Association for the Solar Energy Era, :... I do view the energy problem ... as an extensive political, economic, and social, problem existing on a global scale. Mankind has no alternative but to turn to solar energy. ... Solar-energy management must be implemented without delay and as widely as possible ... An abstract consensus already exists in favour of solar energy ... Converting this into a concrete, effective consensus is one of the main tasks of this Association'.
These were the buoyant words of Dr Hermann Scheer, the West German MP who is Chairman of EuroSolar, in his keynote speech to the organization's foundation assembly in Bonn, West Germany, in August 1988. The organization's aim is to do everything in its power to ensure that the world's energy supply is switched away from fossil fuels and over to inexhaustible sources of energy - such as solar energy, wind and hydraulic power, and hydrogen produced by means of solar energy. 